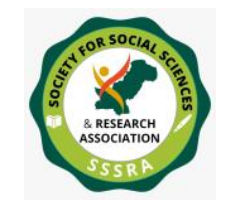

Pak. Journal of Int'L Affairs, Vol 4, Issue 4 (2021) Insight on COVID-19 Phenomena in the Initial ...

\title{
INSIGHT ON COVID-19 PHENOMENA IN THE INITIAL PHASE: MAINSTREAM INDIAN VS. PAKISTANI NEWSPAPERS
}

\author{
Noman Ishfaq \\ M.Phil. Scholar \\ Department of Media Studies, \\ The Islamia University of Bahawalpur \\ Bahawalpur - Pakistan \\ nomanishfaq786@gmail.com \\ Awais H. Gillani \\ Assistant Professor \\ Department of Media Studies \\ The Islamia University of Bahawalpur \\ Pakistan. \\ Corresponding author: $\underline{\text { ahgillani@iub.edu.pk }}$ \\ Saleem Akhtar \\ Lecturer \\ Faculty of Media and Communication Studies \\ University of Central Punjab \\ Lahore - Pakistan \\ saleemakhtar@ucp.edu.pk
}

\begin{abstract}
The mysterious COVID-19 phenomenon has become an infodemic. This study aims to understand the communication phenomenon of the devious virus critically. Employing thematic analysis and framing theory, the study analyzed the editorials of Dawn and the Hindustan Times published from March 1, 2020, to March 31, 2020. After rigorous mining of the data, using open and axial coding, four major themes came out, which are (1) Shutting down the country, (2) COVID-19 and economic trauma, (3) Health management challenges, and (4) countering the infodemic. The findings indicated that most editorials added to people's knowledge about COVID-19. The editorials informed the policy-makers and citizens on pandemic issues like the need for lockdown, severeness of infectious disease, drastic consequences on the global economy. This study is an




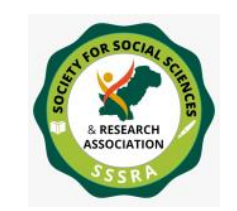

Pak. Journal of Int'L Affairs, Vol 4, Issue 4 (2021) Insight on COVID-19 Phenomena in the Initial ...

addition to the COVID-19 communication literature that helped decode the COVID-19 communication phenomenon from Pakistani and Indian newspapers' perspectives.

Keywords: English Newspapers, India, Pakistan, Lockdown, Economy, Health, Infodemic, Editorials, COVID-19, Thematic analysis.

\section{Introduction}

In contemporary human civilization, universal epidemics' danger deems the most crucial threat (see, Davis, 2005; Elbe, 2010; Fidler, 2004; Leuzinger-Bohleber, M., \& Montigny, N., 2021; Durrheim, D. N., Andrus, J. K., Tabassum, S., Bashour, H., Githanga, D., \& Pfaff, G., 2021). Epidemics pose a fatal risk that can slay over $25 \%$ of a population (Morens, Folkers, \& Fauci, 2004). Nowadays, the world is suffering SARS-CoV-2 (Severe acute respiratory syndrome-coronavirus-2), a global pandemic, the infection resulting in COVID-19 disease (World Health Organization, 2020). This contagious disease has some indications, including dry cough, fever, problems in breathing, aches, throat pain, and some people will experience running nose and diarrhea. As reported in many media reports, Wuhan's seafood market in China is allegedly suspected as the locus of the COVID-19 pandemic.

COVID-19 has affected every phase of life, including economy, society, culture, art, sports, environment, politics, etc. Hundreds of significant events country-wide and worldwide were discontinued or delayed due to the coronavirus, including the Tokyo Olympics (The New York Times, 2021). Panic buying is the reason for the extensive shortage of daily life supplies (Scipioni, J., 2020). "The best way to prevent and slow down transmission is to be well informed about the disease and how the virus spreads" (World health organization, 2020). At the time of the epidemic, media is crucial about awareness of COVID-19 and increasing the possibility of current human social existence.

Mass media has a dynamic impact on people's minds and influences their actions. People from every aspect of society depend on media for information. In the $21^{\text {st }}$ century, social media is pivotal. However, newspapers play a significant role in health emergencies to develop public discussion and policies (Dry \& Leach 2010). Editorial is an opinion or argument presented by editors as an official policy of the news organization. After the vaccine, communication is the biggest weapon to deal with the pandemic (Barry, J. M. 2009). Print media is a vital component of mass communication in disseminating information at the mass level. The editorial section of the newspaper is the central part of any newspaper. It highlights the most critical events and expresses an official opinion of 
the news organization. This study focuses on the editorial section of two mainstream Indian and Pakistani newspapers-Hindustan Times and Dawn. The researchers choose Indian and Pakistani newspapers because the two neighboring countries share the same living, working, cultural and environmental conditions.

Four different themes evolve after reading editorials word by word:

(1) Economy,(2) Health, (3) Lockdown, and (4) Infodemics.

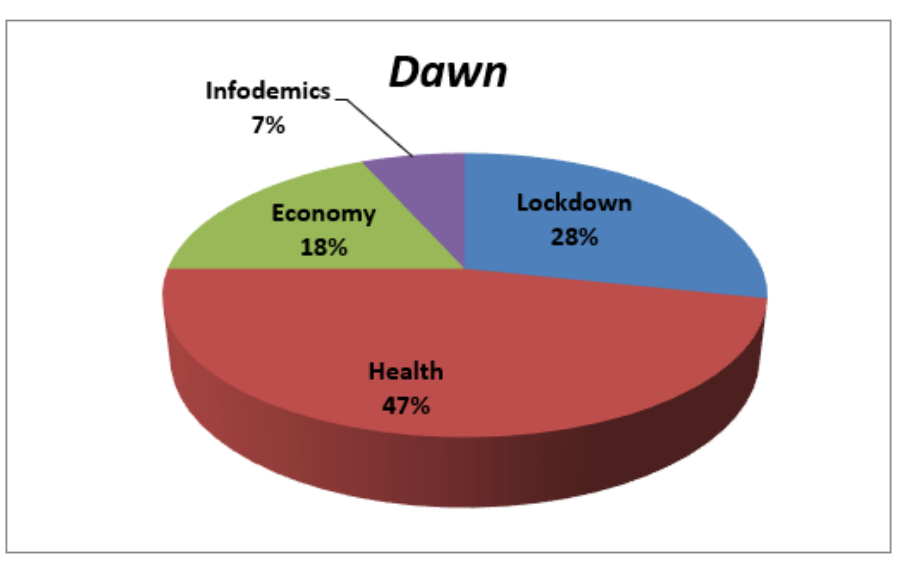

*a graphical representation of coverage percentage given to different themes by Dawn Newspaper, Pakistan.

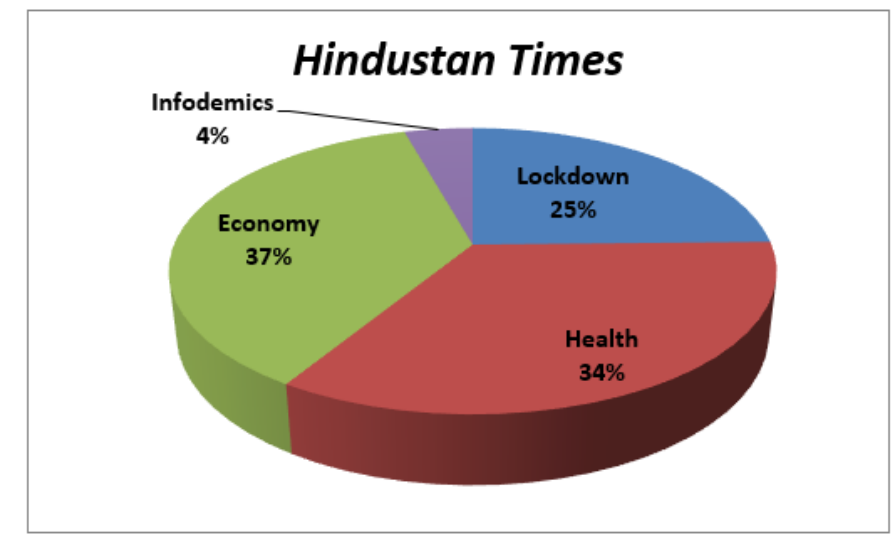

*a graphical representation of coverage percentage given to different themes by Hindustan Times, India. 


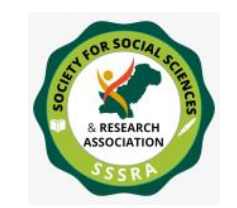

Pak. Journal of Int'L Affairs, Vol 4, Issue 4 (2021) Insight on COVID-19 Phenomena in the Initial ...

\section{Literature Review}

\subsection{COVID-19 and Communication}

Undoubtedly the coronavirus pandemic has seized the world and brought an information crisis. In the information crisis, a practical communicative attitude to acquire correct information is critical and essential. Reliability of information in the time of the COVID-19 pandemic is an enormous dilemma. The need for information exceptionally shoots up, particularly news, to the transition of the epidemic (Edelman, 2020).

\subsection{COVID-19 Misinformation and Fake News}

Social and digital platforms are the vibrant origin of misinformation. Furthermore, misinformation and disinformation are merely systemic attempts to take advantage of personal or political interests, get power, and influence beliefs. Although conspiracy theorists initially speculated that the virus originated from a lab in Wuhan, Chinese scientists rejected such accusations (Calisher et al., 2020). Misinformation overflow at the time of crisis, a society that is misinformed can bring havoc worldwide. Opportunists from the virtual world are working hard to benefit from people's distress; with the help of ecommerce and different social media forums, they are trading in medication, contending that it is the solution of COVID-19 (Heilweil, R., 2020).

\subsection{Framing of COVID-19 in Pakistan and India}

People's opinion framing related to the nation's combined opinion is essential in an issue like Covid-19. One of the most significant characteristics of framing study is understanding and examining the impact of different frames on general public consciousness. Different news frames can affect people with varying results on the same issue. In health emergencies, messages for the general public are framed to give decision power to the people, and it will help the people understand the situations. Media play a crucial part in framing health emergencies, as revealed in empirical studies (see, e.g., Yu, J., Lu, Y., \& Muñoz-Justicia, J. 2020). In this regard, Pakistani and Indian newspapers are presenting some essential frames; awareness of Covid-19; information about SOP's; preventive measures to stop transmission of COVID-19 like social distancing, hand washing, wearing face mask, need of lockdown, health infrastructure and paramedics, economic consequences of COVID-19 and mental health issues.

\section{Data, Methodology and Theoretical Framework}

\section{1: Data}




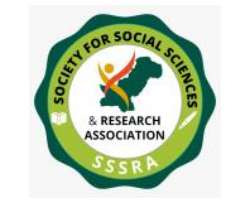

Pak. Journal of Int'L Affairs, Vol 4, Issue 4 (2021) Insight on COVID-19 Phenomena in the Initial ...

Editorials related to COVID-19 published in the mainstream Indian and Pakistani newspapers Hindustan Times and Dawn from March 1, 2020, to March 31, 2020, were selected for this study. In the month of March 1, 2020 to March 31, 2020, both the leading dailies of India and Pakistan published 14 editorials on COVID-19 phenomena. All the published editorials on COVID-19 in the month of March 2020 are taken as a unit of analysis.

Table:

The following table gives a brief description of selected newspapers.

\begin{tabular}{|c|c|c|c|c|c|c|}
\hline $\begin{array}{c}\text { Name of } \\
\text { Newspapers }\end{array}$ & Country & $\begin{array}{c}\text { Geographical } \\
\text { location }\end{array}$ & $\begin{array}{c}\text { First } \\
\text { Publication }\end{array}$ & Type & $\begin{array}{c}\text { Approx. } \\
\text { Circulation }\end{array}$ & $\begin{array}{c}\text { Duration } \\
\text { of this } \\
\text { Study }\end{array}$ \\
\hline Dawn & Pakistan & South Asia & $\begin{array}{c}\text { October 12, } \\
1942\end{array}$ & $\begin{array}{c}\text { Print } \\
\text { and E- } \\
\text { Paper }\end{array}$ & 120,000 & $\begin{array}{c}\text { March } \\
2020\end{array}$ \\
\hline $\begin{array}{c}\text { Hindustan } \\
\text { Times }\end{array}$ & India & South Asia & $\begin{array}{c}\text { September } \\
26, \\
1924\end{array}$ & $\begin{array}{c}\text { Print } \\
\text { and E- } \\
\text { Paper }\end{array}$ & 945,221 & $\begin{array}{c}\text { March } \\
2020\end{array}$ \\
\hline
\end{tabular}

\section{2: Methodology}

The study uses thematic analysis method of Braun \& Clarke (2006). Qualitative methods are exceptionally distinct, manifold, and subtle (Holloway \& Todres, 2003), and thematic analysis is a primary method of qualitative research. The coding procedure is the component of research (Miles \& Huberman, 1994). The current study focuses on the data mining approach using the open coding method. The primary trait of mining-text is its promptness, information acquired from online text streams, and instantly accessible for several usages (Pyo \& Kim, 2019).

\section{3: Theoretical Framework}

This study uses media framing theory. Media framing helped a lot in seeking important information related to pandemics (Liu and Kim, 2011). Framing helps media capturing the public's attention regarding a specific phenomenon (Entman, 2007).

\section{4: Significance of the Study}

The significance of this period is crucial because most of the countries of the world, including Pakistan and India, imposed a lockdown in March after the declaration of the coronavirus as a global pandemic. This study helps to understand the COVID-19 phenomena in its initial phase when the world was complete unaware of its dangers, complexities and challenges.

\section{Findings}




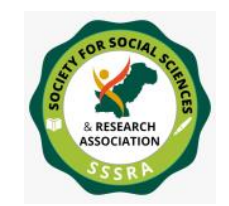

Pak. Journal of Int'L Affairs, Vol 4, Issue 4 (2021) Insight on COVID-19 Phenomena in the Initial ...

In the initial one month of the epidemic, editorials related to the COVID-19 epidemic in mainstream newspapers of India and Pakistan are analyzed. Four dominant themes appeared during March 1, 2020-March 31, 2020 editorial coverage of concerning COVID-19 of Hindustan Times and Dawn.

The section below presents results according to the four themes related to COVID19 communication phenomena.

(1) Shutting down the country (2) COVID-19 and economic trauma (3) Health management challenges (4) Countering the infodemic.

\subsection{Shutting Down the Country}

Lockdown is the only option to minimize the risk and save the citizens' lives at a time of great danger. After the announcement of COVID-19, a "pandemic" (World Health Organization, 2020) for the world, the best potential preventative measure to diminish the transmission of virus countries was shutting down. Most European countries declared the lockdown on March 23 after the grim situation of COVID-19 (Walker, 2020). All the educational institutions, whether public or private, will be shut down, including shopping malls, all types, and public gatherings and traveling, are now restricted. Throughout the human history of pandemics, these restrictions have existed (Jahanbegloo R., 2020). Pakistan and India observed an extensive shutdown across the country from March 2020.

An editorial published in Hindustan Times about the shutting down of the country discussed that it is a fact that the lockdown is a harsh step for a country like India, whose population is 1.3 billion; still, it is necessary to take action, and citizens must follow the government's instructions (Hindustan Times, 2020a). If lockdown is thriving and people observe the instructions, there may be a slower spread of Covid-19. Hindustan Times (2020b) recommends some measures that government should take immediately, i.e., monitor the situation strictly, there may be the possibility to extend the lockdown, the government should draw up an economic plan for poor and daily wagers, the government should also improve the health infrastructure and equip paramedics with essential facilities.

An editorial published in Dawn suggests that a country-wide lockdown is compulsory to stop the transmission of COVID-19. Coronavirus spread rate increases through physical contact; that is why a complete closure is required now, i.e., total ban on national and international traveling and closing borders with Iran and Afghanistan (Dawn, 2020a). There are two opinions on a complete shutdown. Both are factual; the country's economic conditions cannot afford the lockdown; the situation would be worse for the poor 


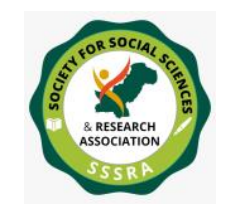

Pak. Journal of Int'L Affairs, Vol 4, Issue 4 (2021) Insight on COVID-19 Phenomena in the Initial ...

people to meet both ends. On the other hand, if we delay lockdown, the COVID-19 problem may worsen; hence, governments should proactively take measures (Dawn, 2020b).

Under this theme, both newspapers present the seriousness of the infectious disease of COVID-19 and encourage the government to take the right step of lockdown for the safety of their citizens for breaking the chain of COVID-19 transmission. Dawn emphasizes that all the political parties must forget party interest and show national interest (Dawn, 2020c). The government should force the citizens to follow the given instructions and SOPs (Standard Operating Procedures). While Hindustan Times focuses on the citizens' behavior, the supply chain of essential goods and suggests that services should continue (Hindustan Times, 2020c). Both the newspapers provide information to the people and educate them regarding the deadly coronavirus.

\subsection{COVID-19 and Economic Trauma}

After the outbreak of COVID-19, all the nations are in an impasse situation-socially and economically. The pandemic enormously affected the economy of the countries. Coronavirus stopped all economic activities. The World Bank and World Health Organization jointly presented an assessment in 2019 about the impact of global GDP at 2.2 percent to 4.8 percent, which was startling (Chaudhry et al., 2020). We observed the economies surrounding this "catastrophe," and this foretell looks genuine. The epidemic coronavirus appeared when economies of the world were more incorporated. This incorporation is the leading cause of the hasty divergence of the COVID-19 worldwide and proved as a catalyst for economic distress (Sharma et al., 2020). Coronavirus pandemic has multispectral effects on the financial activities of the world.

Editorial published in Hindustan Times regarding the economy convey that so many sectors are disturbed economically (Hindustan Times, 2020d). There are some assessments by the United Nations that the Indian economy will bear $350 \$$ million loss on trade and development (Hindustan Times, 2020e). Indian Economy does not depend much on China; hence there may be no direct impact on the Indian economy like other countries with direct economic dealings with China (Hindustan Times, 2020f). Across the world, COVID-19 has drastic consequences on the global economy. Safety measures are suitable, but the closing of everything is a big problem for economic activities. It is becoming a significant cause of unemployment. At this stage, the government should take the essential decisions for that daily wagers who do not operate with the formal economy. Due to coronavirus, factories production reduced, and unemployment increased, ordinary people, are without a source of revenue and facing a shortage of basic needs.

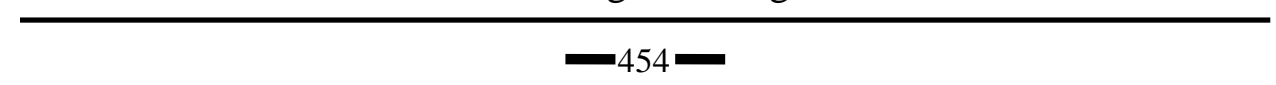




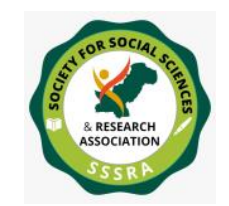

Pak. Journal of Int'L Affairs, Vol 4, Issue 4 (2021) Insight on COVID-19 Phenomena in the Initial ...

Dawn (2020d) says that China is a global economic hub; due to the massive lockdown in China, the world's economies are under colossal pressure. The lockdown in China has disrupted the supply chain worldwide. There is a severe shortage of labor for industry. At the initial stage of the COVID-19 outbreak, the virus is not spreading rapidly in Pakistan, but cases are increasing slowly. According to some experts, it is a good thing regarding exports. However, if we close our eyes and behave shortsighted, the situation could be horrible. Due to globalization and interconnected economic systems, transport, aviation, shipping, tourism is going downswing. For instance, the IMF rescues the developing countries and makes them bound to spend the money on health; it would be an outstanding initiative for providing resources in their hands. This economic trauma will worsen very soon if the financial managers and their corresponding team do not develop a consensus about immediate decisions.

Both newspapers present deep thoughts about the economic conditions of different sectors. Hindustan Times has a point of view that India's economy is not linked with China; India considers it a positive sign (Hindustan Times, 2020g). Moreover, Pakistan believes that lockdown has slowed down the supply chain globally. Editorials under this theme explained that coming days are crucial, and now economic decisions will decide the country's future.

\subsection{Health Management Challenges}

The COVID-19 phenomena harshly affected the countries' health systems worldwide. This outbreak of COVID-19 is damaging the healthcare system of developing countries. Due to this, it is becoming more dangerous for society. The pandemic is taking the developing states to havoc with their neglected and underfinanced public health care system (Gates, 2020). It is a bold wake-up call concerning the poor health infrastructure and medical facilities. Health professionals and experts fear that the consequences of allowing this pandemic to spread without bold decisions and reliable management options may cause unprecedented devastation for humans (Prompetchara et al., 2020). The health care systems of developing countries will be overloaded with an excessive amount of COVID-19 cases. The situation would be deplorable in those countries where health care policies and strategies are weak. It would become a tragedy due to a sudden increase in COVID-19 outbreaks for different regions (Lai et al., 2020).

Editorial published regarding health issues in Hindustan Times describes that at the initial pandemic stage, the Indian government felt hesitant testing the infected peoples and could not test every citizen in the country. The Indian government is doing too little for a country whose population is 1.37 billion and taking an initial random sample of 1,100 


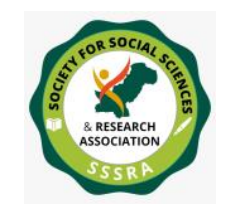

Pak. Journal of Int'L Affairs, Vol 4, Issue 4 (2021) Insight on COVID-19 Phenomena in the Initial ...

people (Hindustan Times, 2020h). It is indispensable to manage the situation very carefully to counter health crises. Editorial suggests that a public-private partnership is a decision to immediately ramp up the testing capacity and fight against outbreaks (Hindustan Times, 2020i). The government should allow private hospitals and labs for COVID-19 tests. It is the direst health emergency, and it needs highly appropriate measures to manage these crises (Hindustan Times, 2020j).

Pakistan faces many health challenges; hence Dawn's editorials focus on the grim health situation. There is a shortage of proper equipment in Pakistani hospitals, and medical staff is not fully trained to deal with the pandemic (Dawn, 2020e). Due to limited paramedical staff, the workload is increasing rapidly, which will cause another big trouble (Dawn, 2020f). To manage these shortcomings, coordination and proper planning are required (Dawn, 2020g). It is important to follow health protocols to avoid virus transmission to medical personnel from infected individuals (Dawn, 2020h). To deal with the situation government should take decisions in advance, and citizens must show responsible behavior (Dawn, 2020i).

Under this theme, both newspapers talk about managing this health crisis, shortage of testing kits and personal safety equipment is an essential issue. The paramedical staff is under massive virus threat due to direct dealing with the infected people. Proper training and personal safety are necessary for frontline workers. The fact presented in both newspapers informs the decision-makers, policy, and planning sections to think out of the box and take compulsory measures to fight against this immensely growing health crisis.

\subsection{Countering the Infodemic}

The dispersion of information during pandemics has been widespread and extensively without authenticity and reliability. After announcing the "pandemic,"a vast wave of information about COVID-19 caused the misinformation (Mheidly \& Farse, 2020). WHO called this phenomenon a serious "Infodemic" through this spread of false news and misinformation quickly and more than the virus (Yuan et al., 2020). The definition of "Infodemic" is that due to some particular occurrence, a heavy increase of inaccurate information about a specific issue, and its spread in a brief time (Zarocostas, 2020). Infodemic/false news caused anxiety, uncertainty, panic, and nervousness.

This fake news and misinformation situation was observed during pandemics worldwide, including Pakistan and India. Hindustan Times (2020k) discusses that COVID19 is a new phenomenon with no recent history. In every part of the world, peoples' concerned regarding the symptoms of this infectious disease and the possible treatment 


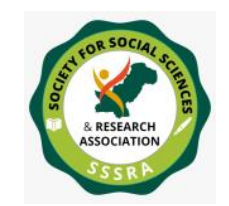

Pak. Journal of Int'L Affairs, Vol 4, Issue 4 (2021) Insight on COVID-19 Phenomena in the Initial ...

procedures and protocol. These circumstances caused fear, panic, anxiety, and uncertainty among the citizens and were converted into misinformation; hence fake news spread rapidly due to that factor. Hindustan Times (20201) reports that people infected with this deadly virus feel shame and guilt and face racial assault. To counter this situation, the government must start counseling and mental therapy for the suspected people and patients because people's mental health suffers a lot (Hindustan Times, 2020m).

The editorials published in Dawn describe that different social media platforms disseminate misleading information about virus symptoms and their cure (Dawn, 2020j). In Pakistan, some of the messages spread rapidly as a homemade remedy for COVID-19 are drinking garlic water, taking hot air through nostrils, and a fake notification circulating. Dawn emphasizes that citizens must follow authentic news sources and do not believe in photoshoped images, understand the country's situation, and behave like a responsible citizen; if the information is not trustworthy, do not spread it to others (Dawn, 2020k).

Both newspapers' editorials present this theme with a little bit of difference. Hindustan Times focuses on mental health because people target infected persons due to lack of knowledge or misinformation. The victims need empathy and kindness from the community. Dawn talks about the community's myths, causing misinformation and fake news. According to the newspaper, people must follow reliable news sources for this pandemic situation and not forward any information that makes trouble for society.

\section{Discussion and Conclusion}

Communication protocols by the government and its different community awareness departments have played a vital role in dealing with the pandemic dilemma. People understand health issues more when the media frames the health issues. Media frame issues to understand crisis coverage (Durham, 1998; Haider-Markal, Delehanty, \& Beverlin, 2007). Media framing of COVID-19 educates the community in acquiring needed preventive measures to control the pandemic and confine the morbidity and fatality ratio. As framing greatly depends on emotions, ideas, and concepts reserved in human memory; hence media frames draw their basis to cognitive psychology in the condition of node and related to one another across the semantic path (Price \& Tewksbury, 1997).

A theme of "shutting down the country" is integrated with a set of media frames related to the need for lockdown in the clearing of the COVID-19 chain of transmission; the brutality of infectious diseases; preventative measures; and the continuation of supply chain services. 
Under the theme "COVID-19 and economic trauma", there are frames that refer to current economic conditions, the impact of the epidemic on the economy, the interconnectedness of economies, and the IMF's rescue plan. These implications will have severe consequences for the global economy. Editorials belong to this theme were significant for decision-makers to counter a massive economic trauma.

Editorials falling under the theme of "Health management challenges" are framing issues on the massive scale of health crisis; medical equipment shortage; necessary health protocols; fatal threat to frontline workers from the virus; health management shortcomings. This information is primarily for health managers and policymakers to take essential measures against the rapidly intensifying health emergency.

Editorials dealing with the theme "Countering the infodemics" are accompanied by frames that describe misinformation, empathy, fake news, mental health, lack of knowledge, anxiety and explain the necessity for citizens to follow credible circumstances in the present situation. As a result, the research supported the idea that the media can use framing to draw attention to a particular issue (Entman, 2007). 
Pak. Journal of Int'L Affairs, Vol 4, Issue 4 (2021) Insight on COVID-19 Phenomena in the Initial ...

\section{References:}

Arshed, N., Meo, M. S., \&Farooq, F. (2020). Empirical assessment of government policies and flattening of the COVID 19 curve. Journal of Public Affairs, 20(4), e2333.

Barry, J. M. (2009). Pandemics: avoiding the mistakes of 1918. Nature, 459(7245), 324325.

Braun, V., \& Clarke, V. (2006). Using thematic analysis in psychology. Qualitative research in psychology, 3(2), 77-101.

Calisher, C., Carroll, D., Colwell, R., Corley, R. B., Daszak, P., Drosten, C. \& Turner, M. (2020). Statement in support of the scientists, public health professionals, and medical professionals of China combatting COVID-19.The Lancet, 395(10226), e42e43.

Chaudhary, M., Sodani, P. R., \& Das, S. (2020). Effect of COVID-19 on economy in India: Some reflections for policy and programme. Journal of Health Management, 22(2), 169-180.

Davis, M. (2005). The monster at our door: the global threat of avian flu. New Press. The New York.

Dawn. (2020a, March 24). Lockdown begins [Editorial]. Dawn. Retrieved from https://www.Dawn.com/news/1543321/lockdown-begins

Dawn. (2020b, March 24). Lockdown begins [Editorial]. Dawn. Retrieved from https://www.Dawn.com/news/1543321/lockdown-begins

Dawn. (2020c, March 11). Call for leadership [Editorial]. Dawn. Retrieved from https://www.Dawn.com/news/1539961/call-for-leadership

Dawn. (2020d, March 10). Coronavirus and the economy [Editorial]. Dawn. Retrieved from https://www.Dawn.com/news/1539666/coronavirus-and-the-economy

Dawn. (2020e, March 29). Fromt-line warriors [Editorial]. Dawn. Retrieved from https://www.Dawn.com/news/1544634/front-line-warriors 


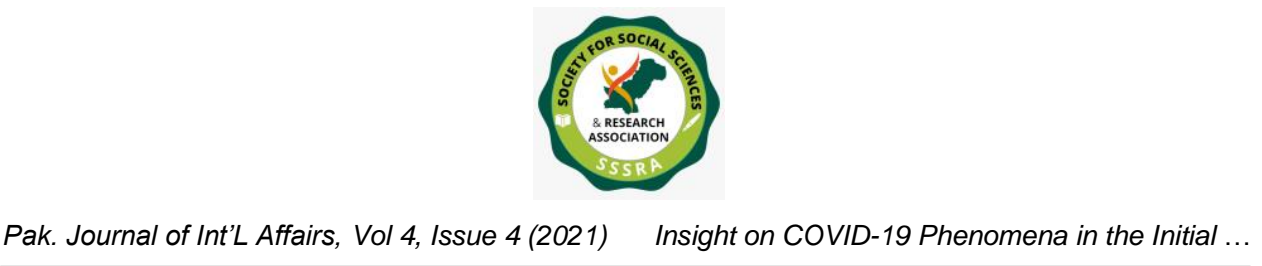

Dawn. (2020f, March 29). Fromt-line warriors [Editorial]. Dawn. Retrieved from https://www.Dawn.com/news/1544634/front-line-warriors

Dawn. (2020g, March 29). Fromt-line warriors [Editorial]. Dawn. Retrieved from https://www.Dawn.com/news/1544634/front-line-warriors

Dawn. (2020h, March 29). Fromt-line warriors [Editorial]. Dawn. Retrieved from https://www.Dawn.com/news/1544634/front-line-warriors

Dawn. (2020i, March 29). Fromt-line warriors [Editorial]. Dawn. Retrieved from https://www.Dawn.com/news/1544634/front-line-warriors

Dawn. (2020j, March 31). Covid-19 misinformation [Editorial]. Dawn. Retrieved from https://www.Dawn.com/news/1545170/covid-19-misinformation

Dawn. (2020k, March 31). Covid-19 misinformation [Editorial]. Dawn. Retrieved from https://www.Dawn.com/news/1545170/covid-19-misinformation

Dry, S., \& Leach, M. (Eds.). (2010). Epidemics: science, governance and social justice. Routledge.

Durham, F. S. (1998). News frames as social narratives: TWA Flight 800. Journal of communication, 48(4), 100-117.

Durrheim, D. N., Andrus, J. K., Tabassum, S., Bashour, H., Githanga, D., \& Pfaff, G. (2021). A dangerous measles future looms beyond the COVID-19 pandemic. Nature Medicine, 27(3), 360-361.

Edelman (2020). "Special report": Trust and the coronavirus. Retrieved from Elbe, S. (2010).Haggling over viruses: the downside risks of securitizing infectious disease. Health Policy and Planning, 25(6), 476-485.

Entman, R. M. (2007). Framing bias: Media in the distribution of power. Journal of communication, 57(1), 163-173.

Fidler, D. P. (2004).Brief history of the global SARS outbreak of 2002-03.In SARS, Governance and the Globalization of disease (pp. 71-105). Palgrave Macmillan, London 


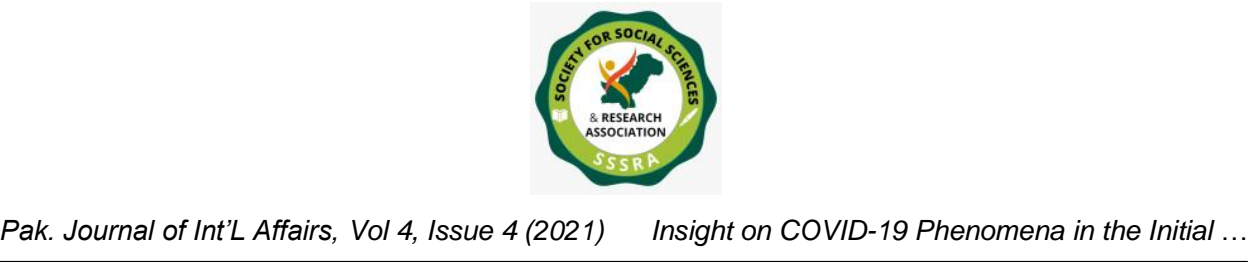

Gates, B. (2020). Responding to Covid-19-a once-in-a-century pandemic?. New England Journal of Medicine, 382(18), 1677-1679.

Haider-Markel, D. P., Delehanty, W., \&Beverlin, M. (2007).Media framing and racial attitudes in the aftermath of Katrina. Policy Studies Journal, 35(4), 587-605.

Heilweil, R. (2020, April 17). Coronavirus scammers are flooding social media with fake cures and tests. Retrieved from https://www.vox.com/recode/2020/4/17/21221692/digital-black

Hindustan Times. (2020a, March 25). The mechanics of the lockdown [Editorial]. Hindustan Times. Retrieved from https://www.hindustantimes.com/editorials/themechanics-of-the-lockdown-ht-editorial/story-ezXq1AY1OuQjIZkzQn3EDK.html

Hindustan Times. (2020b, March 18). Draw up a new economic plan [Editorial]. Hindustan Times. Retrieved from https://www.hindustantimes.com/editorials/covid-19-drawup-a-new-economic-plan-ht-editorial/story-oHNO0mYheTizP62sD2eLxO.html

Hindustan Times. (2020c, March 18). Draw up a new economic plan [Editorial]. Hindustan Times. Retrieved from https://www.hindustantimes.com/editorials/covid-19-drawup-a-new-economic-plan-ht-editorial/story-oHNO0mYheTizP62sD2eLxO.html

Hindustan Times. (2020d, March 16). Covid-19 and its economic impact [Editorial]. Hindustan Times. Retrieved from https://www.hindustantimes.com/editorials/covid19-and-its-economic-impact/story-DSkL0CqDekLDNm0BrgQnuO.html

Hindustan Times. (2020e, March 16). Covid-19 and its economic impact [Editorial]. Hindustan Times. Retrieved from https://www.hindustantimes.com/editorials/covid19-and-its-economic-impact/story-DSkL0CqDekLDNm0BrgQnuO.html

Hindustan Times. (2020f, March 16). Covid-19 and its economic impact [Editorial]. Hindustan Times. Retrieved from https://www.hindustantimes.com/editorials/covid$\underline{\text { 19-and-its-economic-impact/story-DSkL0CqDekLDNm0BrgQnuO.html }}$

Hindustan Times. (2020g, March 16). Covid-19 and its economic impact [Editorial]. Hindustan Times. Retrieved from https://www.hindustantimes.com/editorials/covid19-and-its-economic-impact/story-DSkL0CqDekLDNm0BrgQnuO.html

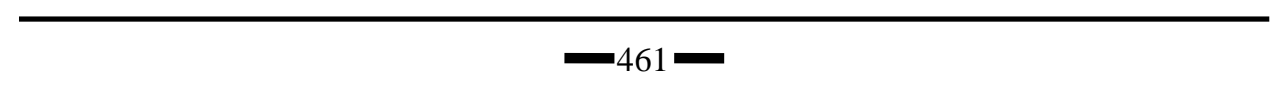


Pak. Journal of Int'L Affairs, Vol 4, Issue 4 (2021) Insight on COVID-19 Phenomena in the Initial ...

Hindustan Times. (2020h, March 17). Ramp up testing, now [Editorial]. Hindustan Times. Retrieved from https://www.hindustantimes.com/editorials/ramp-up-testing-now-hteditorial/story-Kzy1k0TGZ8N1tn2gcLrIoJ.html

Hindustan Times. (2020i, March 17). Ramp up testing, now [Editorial]. Hindustan Times. Retrieved from https://www.hindustantimes.com/editorials/ramp-up-testing-now-hteditorial/story-Kzy1k0TGZ8N1tn2gcLrIoJ.html

Hindustan Times. (2020j, March 17). Ramp up testing, now [Editorial]. Hindustan Times. Retrieved from https://www.hindustantimes.com/editorials/ramp-up-testing-now-hteditorial/story-Kzy1k0TGZ8N1tn2gcLrIoJ.html

Hindustan Times. (2020k, March 19). Dealing wih the human condition [Editorial]. Hindustan Times. Retrieved from https://www.hindustantimes.com/editorials/dealing-with-the-human-condition/story0M6ImRe1QiN8psmSjWPmzL.html

Hindustan Times. (20201, March 19). Dealing wih the human condition [Editorial]. Hindustan Times. Retrieved from https://www.hindustantimes.com/editorials/dealing-with-the-human-condition/story0M6ImRe1QiN8psmSjWPmzL.html

Hindustan Times. (2020m, March 19). Dealing wih the human condition [Editorial]. Hindustan Times. Retrieved from https://www.hindustantimes.com/editorials/dealing-with-the-human-condition/story0M6ImRe1QiN8psmSjWPmzL.html

Holloway, I., \&Todres, L. (2003). The status of method: flexibility, consistency and coherence. Qualitative research, 3(3), 345-357.

https://www.edelman.com/research/2020-edelman-trust-barometer-special-reportcoronavirus-and-trust https://www.nytimes.com/article/cancelled-events-coronavirus.html

Jahanbegloo, R. (2020, March 27). Life lessons from the history of lockdowns. Mint. Retrieved from https://www.livemint.com/news/india/life-lessons-from-the-historyof-lockdowns-11585312953744.html

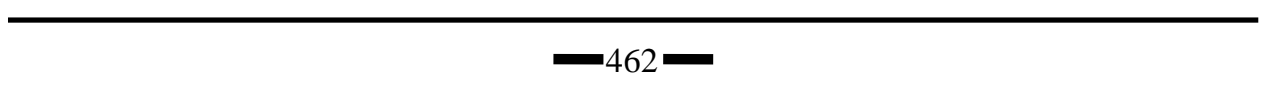




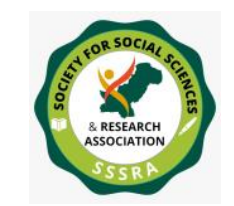

Pak. Journal of Int'L Affairs, Vol 4, Issue 4 (2021) Insight on COVID-19 Phenomena in the Initial ...

Lai, C. C., Wang, C. Y., Wang, Y. H., Hsueh, S. C., Ko, W. C., \&Hsueh, P. R. (2020). Global epidemiology of coronavirus disease 2019 (COVID-19): disease incidence, daily cumulative index, mortality, and their association with country healthcare resources and economic status. International journal of antimicrobial agents, 55(4), 105946.

Leuzinger-Bohleber, M., \& Montigny, N. (2021). The pandemic as a developmental risk. International Journal of Applied Psychoanalytic Studies, 18(2), 121-132.

Liao, Q., Yuan, J., Dong, M., Yang, L., Fielding, R., \& Lam, W. W. T. (2020). Public engagement and government responsiveness in the communications about COVID19 during the early epidemic stage in China: infodemiology study on social media data. Journal of medical Internet research, 22(5), e18796.

The New York Times. (2021, January 21, 2021). A List of What's Been Canceled Because of the Coronavirus - From the 2020 Olympics to Broadway shows, here's a look at some major events around the world that have been affected by the new coronavirus. The New York Times. Retrieved from https://www.nytimes.com/article/cancelledevents-coronavirus.html

Liu, B. F., \& Kim, S. (2011). How organizations framed the 2009 H1N1 pandemic via social and traditional media: Implications for US health communicators. Public Relations Review, 37(3), 233-244.

Mheidly, N., \& Fares, J. (2020). Leveraging media and health communication strategies to overcome the COVID-19 infodemic. Journal of public health policy, 1-11.

Miles, M. B., \&Huberman, A. M. (1994). Qualitative data analysis: An expanded sourcebook. Sage.

Morens, D. M., Folkers, G. K., \&Fauci, A. S. (2004). The challenge of emerging and reemerging infectious diseases. Nature, 430(6996), 242-249.

Norris, S. L. (2020). WHO and rapid advice guidelines: history and future directions. 2013 Oversees research to develop corona treatment in Pakistan. (2020, April 16). Dawn. Retrieved from https://www.Dawn.com/news/1549628 


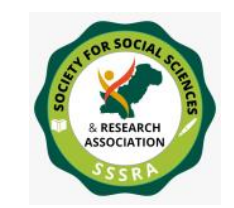

Pak. Journal of Int'L Affairs, Vol 4, Issue 4 (2021) Insight on COVID-19 Phenomena in the Initial ...

Price, V., Tewksbury, D., \& Powers, E. (1997). Switching trains of thought: The impact of news frames on readers' cognitive responses. Communication research, 24(5), 481506.

Prompetchara, E., Ketloy, C., \&Palaga, T. (2020). Immune responses in COVID-19 and potential vaccines: Lessons learned from SARS and MERS epidemic. Asian Pacific Journal of allergy and immunology, 38(1), 1-9.

Pyo, D. J., \& Kim, J. (2019). News media sentiment and asset prices in Korea: text-mining approach. Asia-Pacific Journal of Accounting \& Economics, 28(2), 183-205.

Sandra E. Garcia \& Tariro Mzezewa (2020, 1 April). Canceled Events Because of Coronavirus. The New York Times. Retrieved from

Scipioni, J. (2020). Why there will soon be tons of toilet paper, and what food may be scarce, according to supply chain experts. CNBC (18 March 2020). Retrieved from https://www.cnbc.com/2020/03/18/supply-chain-experts-foods-that-could-be-lessavailable-in-pandemic.html

Sharma, G. D., Talan, G., \& Jain, M. (2020). Policy response to the economic challenge from COVID-19 in India: A qualitative enquiry. Journal of Public Affairs, 20(4), e2206.

Walker, P. (2020). Coronavirus lockdown: What are the new rules announced by Boris Johnson. The Guardian. Retrieved from https://www.theguardian.com/world/2020/may/10/uk-coronavirus-lockdown-whathas-boris-johnson-announced

World Health Organization. (2020, April 25). Coronavirus. Retrieved from https://www.who.int/health-topics/coronavirus\#tab=tab_1

Yu, J., Lu, Y., \& Muñoz-Justicia, J. (2020). Analyzing spanish news frames on twitter during COVID-19-A network study of El País and El Mundo. International journal of environmental research and public health, 17(15), 5414.

Zarocostas, J. (2020). How to fight an infodemic. The lancet, 395(10225), 676.

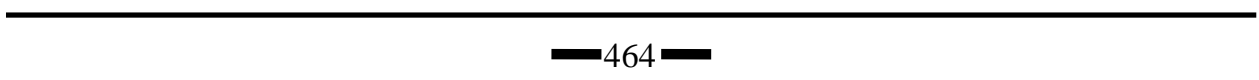

